\section{Удк 338.001.36}

JEL classification: 010, L26

\section{Р. Г. СНІЩЕНКО}

кандидат економічних наук, доцент, докторант,

Тернопільський національний економічний університет, Україна

\section{B. І. ГРИНЧУЦЬКИЙ}

доктор економічних наук, профресор, каредра економіки і економічної теорії, Тернопільський національний економічний університет, Україна

(C) Р. Г. Сніщенко, В. І. Гринчуцький, 2020

Отримано: 15.02.2020 р.

Прорецензовано: 22.02.2020 р.

Рекомендовано до друку: 26.02.2020 р.

Опубліковано: 28.02.2020 p.

\section{(1) (8)}

Ця стаття розповсюджується на умовах ліцензії Creative Commons AttributionNonCommercial 4.0, яка дозволяє необмежене повторне використання, розповсюдження та відтворення на будь-якому носії, за умови правильного цитування оригінальної роботи.
Р. Г. Сніщенко (Україна)

В. І. Гринчуцький (Україна)

\section{ІНФОРМАЦІЙНА БЕЗПЕКА ЯК СКЛАДОВА ЕКОНОМІЧНОї БЕЗПЕКИ СУБ'ЄКТІВ ГОСПОДАРЮВАННЯ}

\begin{abstract}
АНОТАЦІя
Стаття розглянуто визначення і обґрунтування ролі інформаційної складової в економічній безпеці суб'єкта підприємництва. Об'єктом дослідження $\epsilon$ господарські, управлінські і регуляторні процеси суб'єкта господарської діяльності при його функціонуванні в умовах впливу дестабілізуючих факторів. Предметом дослідження виступають теоретичні засади економічної безпеки суб'єкта господарської діяльності. Визначено, що посилення ролі інформаційної складової у забезпеченні економічної безпеки зумовлене цифровізацією, інформатизацією і глобалізацією бізнеспроцесів. Стверджується, що використання результатів науково-технічного прогресу викликає появу нових видів, інструментів і продуктів бізнесу, прискорює виробничі процеси, активізує торгівлю і обмін. Наголошено, що разом з великою кількістю позитивних ефектів впровадження нових технологій відкриває безліч можливостей нашкодити підприємництву. При цьому суб'єктивний фактор в інформаційній безпеці відіграє вирішальну роль, і може як нашкодити бізнесу, так і привести до його процвітання.
\end{abstract}

Сніщенко Р. Г., Гринчуцький В. І. Інформаційна безпека як складова економічної безпеки суб'єктів господарювання. Економічний аналіз. 2020. Том 30. № 1. Частина 1. С. 241-248.

DOI: https://doi.org/10.35774/econa2020.01.01.241

Ключові слова: безпека економічна; безпека інформаційна; процес забезпечення; підприємство; суб'єкт господарської діяльності. 
UDC 338.001.36

\section{JEL classification: 010, L26}

\section{R. SNISHCHENKO}

\section{PhD, Associate Professor}

Doctoral student

Ternopil National Economic University, Ukraine

\section{GRYNCHUTSKYI}

Doctor of Economic Sciences,

Professor,

Department of Economics and Economic Theory,

Ternopil National Economic University, Ukraine

C R. Snishchenko, V. Grynchutskyi, 2020

\section{Received: 15.02 .2020}

Revised: 22.02.2020

Accepted: 26.02.2020

Online publication date: 28.02 .2020

\section{c) (7) (8)}

This is an Open Access article, distributed under the terms of the Creative Commons AttributionNonCommercial 4.0 license, which permits unrestricted re-use, distribution, and reproduction in any medium, provided the original work is properly cited.
R. Snishchenko (Ukraine)

V. Grynchutskyi (Ukraine)

\section{INFORMATION SECURITY AS A COMPONENT OF ECONOMIC SECURITY OF BUSINESS ENTITIES}

\begin{abstract}
The article is devoted to the definition and substantiation of the role of the information component in the economic security of the business entity. The object of study is the economic, managerial and regulatory processes of the subject of economic activity in its operation under the influence of destabilizing factors. The subject of the study are the theoretical foundations of economic security of the business entity. It is determined that the strengthening of the role of the information component in ensuring economic security is due to digitalization, informatization and globalization of business processes. It is claimed that the use of the results of scientific and technological progress causes the emergence of new types, tools and products of business, accelerates production processes, intensifies trade and exchange. With the development of new technologies, the number of incidents related to information leaks and cyberattacks in various fields: in financial and media companies, in the field of nuclear energy and others increases with geometric dependence. It is emphasized that a significant part of companies does not pay enough attention to the creation of full-fledged protection systems. It is determined that with the participating enterprise is not only a technical and technological complex for the production of material goods and services. Most economic security researchers view the enterprise primarily as an association of individuals to achieve a common goal. The staff of the enterprise is both a factor of production and a source of its development. It is emphasized that together with a large number of positive effects of the introduction of new technologies opens up many opportunities to harm business. In this case, the subjective factor in information security plays a crucial role, and can both harm the business and lead to its prosperity. Due to the fact that the issues of information security of economic entities as a component of their economic security have long gone beyond sectoral problems and require further careful study at the level of the state and society as a whole.
\end{abstract}

Snishchenko R., Grynchutskyi V. (2020). Information security as a component of economic security of business entities. Economic analysis, 30 (1, Part 1), 241-248.

DOI: https://doi.org/10.35774/econa2020.01.01.241

Keywords: economic security; information security; security process; enterprise; business entity. 


\section{Вступ}

Розвиток сучасних технологій спричинив появу нових видів, інструментів і продуктів бізнесу, прискорив виробничі процеси, активізував торгівлю і обмін. Разом з цим, з'явилися нові можливості кримінального збагачення, нанесення умисної шкоди економічним ресурсам і діловій репутації підприємств, проведення диверсій і терактів за допомогою ультрасучасних апаратних і програмних засобів. Цьому також активно сприяють глобальна цифровізація бізнесових і виробничих процесів, інтеграція окремих локальних мереж підприємств в єдині галузеві і міжгалузеві інформаційні системи. Інформаційна складова у процесі забезпечення економічної безпеки суб'єктів господарювання набуває все більшої значимості і актуальності.

Економічноїа безпека підприємства $\epsilon$ актуальною темою дослідження для багатьох українських науковців. Серед них: О. А. Сороківська, В. Л. Гевко [1], А. В. Марунич [2], С. Б. Гордієнко, О. С. Микитенко, В. Г. Данильчук [3] та ін. Їх роботи створили міцний фундамент знань з забезпечення інформаційної безпеки підприємництва, але питання щодо аспектів використання сучасних технологій потребують подальшої розробки.

\section{Мета статті}

Метою статті $€$ визначення і обґрунтування ролі інформаційної складової в економічній безпеці суб'єкта підприємництва. Об'єктом дослідження є господарські, управлінські і регуляторні процеси суб'єкта господарської діяльності при його функціонуванні в умовах впливу дестабілізуючих факторів. Предметом дослідження виступають теоретичні засади економічної безпеки суб'єкта господарської діяльності.

\section{Виклад основного матеріалу дослідження}

В сучасних умовах нестабільної економіки впровадження інформаційних технологій у виробничий процес і в інфраструктуру підприємств дає чималу фору у їх конкурентній боротьбі на ринках сировини і збуту продукції. Саме тому кількість підприємств, які використовують комп'ютерні засоби щорічно збільшується (рис. 1).

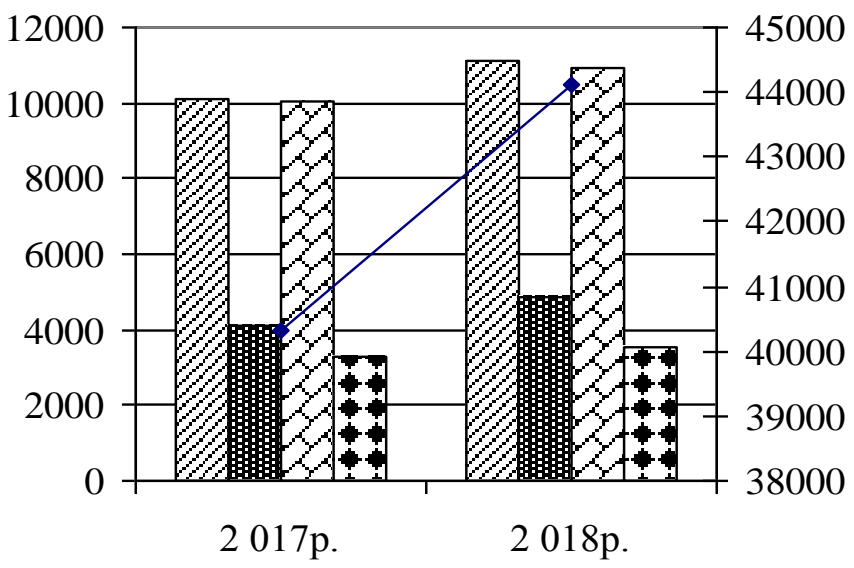

\section{Переробна промисловість $\mathrm{C}$ \\ 嘈祭 Будівництво F}

Оптова та роздрібна торгівля $\mathrm{G}$

Транспорт, складське господарство $\mathrm{H}$

$\rightarrow$ Усього

Рис. 1 Кількість підприємств в Україні, які використовують комп'ютерні засоби у 2010-2018 рр.

Джерело: складено автором по даним [4].

статистики [4] не враховують використання піратського програмного забезпечення, i тому цифри про використання комп'ютерних засобів повинні бути на порядок вище.

Заслуговує на увагу на публікація [5], де зазначається, що «обсяг неліцензійного програмного забезпечення, яке нелегально використовується в Україні, становить близько 82\%, що $\epsilon$ основною причиною хакерських атак на комп'ютери користувачів». 32013 по 2015 рік Україна знаходилася в статусі Priority Foreign Country, що позначає країни 3 найвищим рівнем порушень у сфері інтелектуальної власності (які, у для американських компаній), а також країни, що не бажають вести переговори щодо цих проблемних питань. 32015 року наша країна хоча й знаходиться в «списку 301» (Priority Watch List), але через позитивну динаміку у сфері використання ліцензованого програмного забезпечення i y зв'язку з військовими діями в зоні ООС міжнародні санкції до неї не застосовуються.

Разом 3 використанням комп'ютерів (як загального призначення, так і спеціалізовних) підприємства активно використовують комп'ютерні мережі. По даним Державної служби статистики України [4] у 2018 році 26307 підприємств 
використовували локальну комп'ютерну мережу (LAN), 29129 - мали мережу Інтранет, 4094 підприємства мали мережу Екстранет.

Використання фіксованого широкосмугового з'єднання 3 мережею Інтернет у 2018 році спостерігалося у 30539 суб'єктів господарювання, більшість яких відносяться до підприємств торгівлі та ремонту автотранспортних засобів (26\%), переробної промисловості (25\%), будівництва (10\%) [4]. Слід звернути увагу на те, що показники використання комп'ютерних засобів підприємствами України за даними [4] кожного року зростають приблизно на $10 \%$, і з розвитком новітніх технологій спостерігається стійка тенденція до їх збільшення.

У 2017 році - 39582, а у 2018 році - 43303 підприємств мали доступ до мережі Інтернет [4] У більшості випадків мережу Інтернет використовували для:

- надсилання чи отримання повідомлень електронною поштою;

- здійснення телефонних дзвінків за допомогою Інтернет/VoIP-зв'язку або відео-конференцій;

- отримання інформації про товари та послуги;

- користування миттєвим обміном повідомленнями та електронною дошкою оголошень;

- отримання інформації від органів державної влади;

- здійснення різноманітних операцій з органами державної влади (за винятком отримання інформації);

- здійснення банківських операцій;

- доступу до інших фінансових послуг.

Інформаційна безпека підприємства як складова його економічної безпеки охоплює не тільки проблемну сферу втрат суб'єкта господарювання в результаті реалізації інформаційних загроз, а й проблемну сферу підвищення ефективності його діяльності в результаті впровадження сучасних інформаційних технологій. Це зумовлено також і отриманням додаткового економічного ефекту від реалізації заходів безпеки за допомогою комп'ютеризованих систем.

Додатковий економічний ефект може забезпечуватись за рахунок:

- підвищення службової дисципліни, в першу чергу через використання автоматизованої підсистеми контролю доступу та засобів контролю;

- підвищення ефективності кадрового менеджменту за рахунок використання операцій наскрізного контролю бізнеспроцесів;

- підвищення продуктивності праці персоналу за рахунок виключення непродуктивних витрат часу і ресурсів на основі аналізу відео-архівів;
- оптимізація і узгодження проведення банківських і бухгалтерських операцій, документування особливо важливих подій, аналіз ефективності використання ресурсів і т. ін.

Використання інноваційних технологій наразі набуває все більшої актуальності. Застосування програмно-технічних і технологічних нововведень не тільки підвищує продуктивність праці, а й розширює можливості постачання і сбуту, покращує умови праці, підвищує її безпечність. При цьому загрози економічній безпеці від використання досягнень науково-технічного прогресу 3 злочинною метою є одними з найсуттєвіших через можливість їх дистанційної реалізації і максимальну заподіяну шкоду.

За даними звіту Threat Intelligence Index 2019 корпорації IBM X-Force [6], протягом останніх трьох років відбувся несанкціонований доступ до більше за 11,7 млрд конфіденційних записів і до понад 11 терабайт даних. На думку фахівців, кількість реальних кіберзлочинів перевищує кількість оприлюднених випадків кібератак більше, ніж втричі. В системі У середньому на одну досліджувану компанію у 2018 році припадало 1440 потенційно вразливих місць для кібератак.

у щорічному звіті, виконаному Ponemon Institute [6] на замовлення IBM Security, повідомляється, що середня величина втрат від однієї інформаційної крадіжки складає 3,92 млн доларів. На виявлення крадіжки такого роду може знадобитися декілька місяців, а більшість з них взагалі не відстежуються. Значна частина компаній не приділяє достатньої уваги створенню повноцінних систем захисту.

3 розвитком нових технологій кількість інцидентів, пов'язаних з витоками інформації й кібератаками в різних галузях: у фінансових i медіакомпаніях, у галузі ядерної енергетики та інших збільшується 3 геометричною залежністю. Найвідоміший випадок з комп'ютерним «хробаком» StuxNet. Це перший відомий комп'ютерний хробак, що перехоплює і що модифікує інформаційний потік між програмованими логічними контролерами марки Simatic S7 і робочими станціями SCADA-системи Simatic WinCC фірми Siemens [7]. Таким чином, черв'як може бути використаний як засіб несанкціонованого збору даних (шпигунства) i диверсій в АСУ ТП промислових підприємств, електростанцій, аеропортів і т. ін. [9]

Унікальність програми полягала в тому, що вперше в історії кібератак вірус фізично руйнував інфраструктуру [8]. У 2010 році він став реальною загрозою для основної галузі в економіці Ірану.

Кібератака вірусом Petya у 2017 році, заблокувала діяльність десятків організацій і 
компаній. За оцінкою експертів Reuters [8], економічні втрати від епідемії вірусу Petya.A і його попередника WannaCry по всьому світу можуть скласти \$ 8 млрд. За даними McAfee, в США було зафіксовано більше інфікованих комп'ютерів, ніж на Україні, однак, статистика антивіруса ESET твердить, що більше 80\% зафіксованих заражень відбулися саме на Україні.

Хакерські атаки на Україну - цілеспрямовані масштабні хакерські напади на мережі українських державних підприємств, установ, банків, медіа тощо, які відбулися 27 червня 2017 року. В результаті цих атак була заблокована діяльність таких підприємств, як аеропорт «Бориспіль», ЧАЕС,
Укртелеком, Укрпошта, Ощадбанк, Укрзалізниця та ряду великих комерційних підприємств [7; 10].

Згідно 3 дослідженням IBM X-Force Threat Intelligence Index 2019 [6], у світі сфера фінансів і страхування утримує першість за кількістю кібератак щонайменше протягом трьох років, про це свідчить дослідження (19\% від усіх кібератак). Сфера перевезень, яка ще у 2017-му була на 10 місці, піднялася на друге місце у 2018 році. Відсоток кібератак у цій галузі становить $13 \%$. На третьому місці сфера професійних послуг (наприклад, консалтинг), на четвертому роздрібна торгівля і на п'ятому - виробництво (рис. 2).

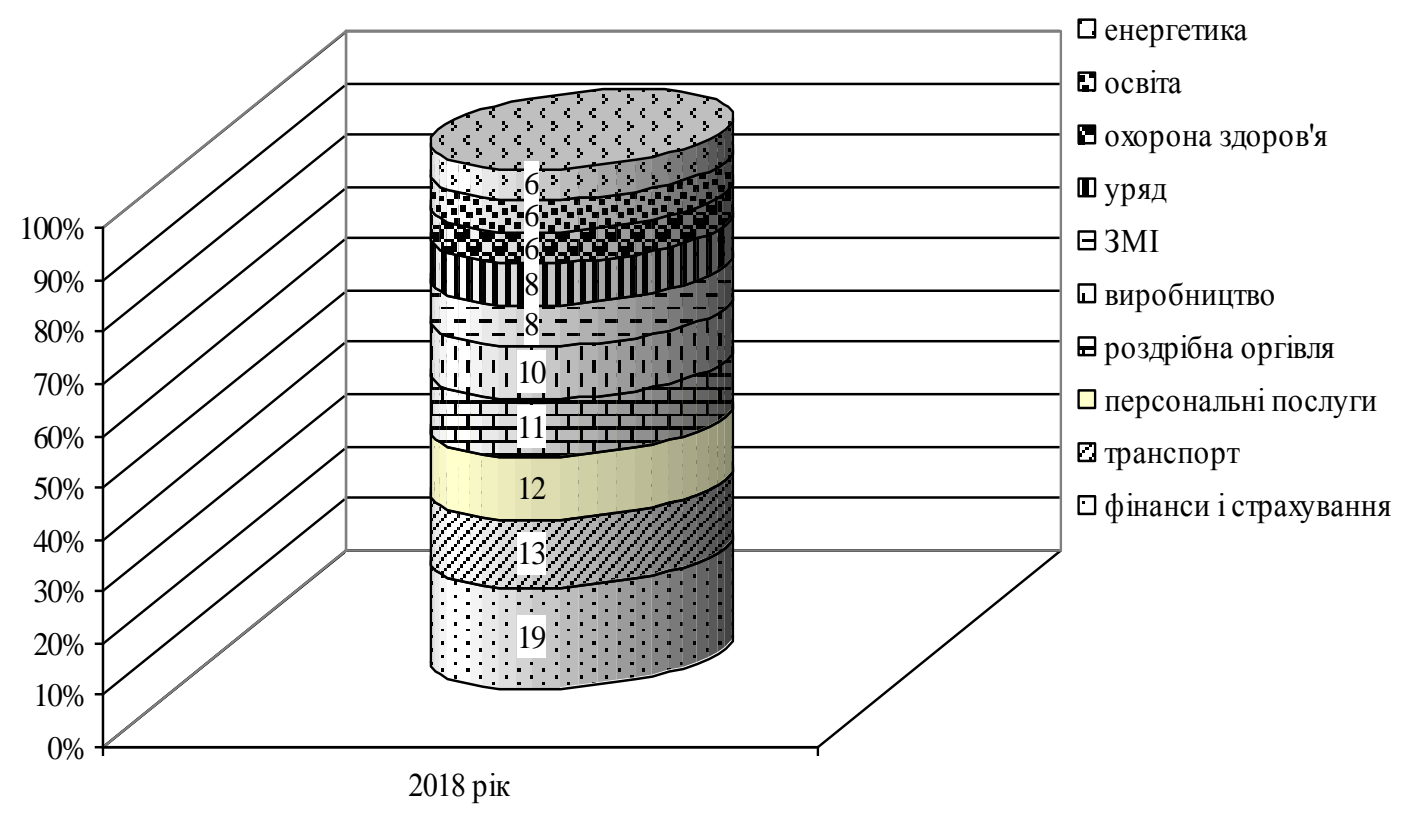

Рис. 2 Найбільш вразливі для кібератак галузі економіки

\section{Джерело: [7]}

Сучасне підприємство - це не лише технікотехнологічний комплекс з виробництва матеріальних благ та послуг. Більшість дослідників економічної безпеки розглядають підприємство перш за все як об'єднання індивидів для досягнення загальної мети. Персонал підприємства $\epsilon$ одночасно і фактором виробництва, і джерелом його розвитку. Тому сучасна підприємницька діяльність має як економічну, так і соціальну спрямованість.

Людський фактор в проблематиці забезпечення економічної безпеки підприємства $€$ одним з головних факторів як зовнішнього, так і внутрішнього впливу. Останнім часом особливої актуальності набувають питання інформаційної і фінансової безпеки, пов'язані 3 діяльністю інсайдерів (рис. 3).

За даними [11] близько 11\% випадків витоку інформації з обмеженим доступом відбувається через халатність співробітників компаній, 14\% через хакерські і вірусні атаки, 31\% - 3 метою навмисного заподіяння матеріальної шкоди власними співробітниками. 


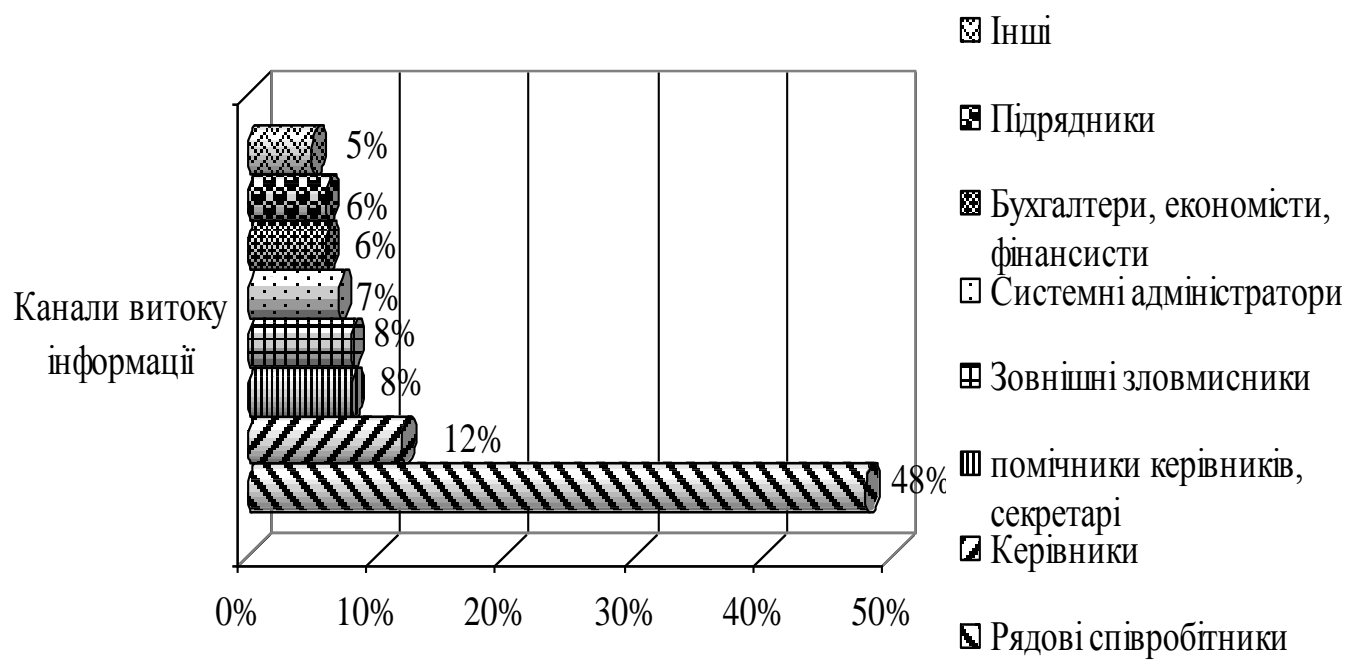

Рис. 3. Канали витоку конфіденційної інформації з вини інсайдерів

Джерело: [11].

За інформацією [12] у 2018 році в світі $24 \%$ витоку конфіденційної інформації відбувалося 3 метою шахрайства. При цьому Росія займає одне 3 провідних місць по розгулу кіберзлочинності в державному секторі.

За даними InfoWatch [12], в 2018 році в світі було зареєстровано 2263 публічних випадків витоку конфіденційної інформації. у 86\% інцидентів були скомпрометовані персональні дані і платіжна інформація - всього близько 7,3 млрд записів призначених для користувача даних проти 13,3 млрд записів даних роком раніше. Таким чином, світовий обсяг витоків призначених для користувача даних скоротився майже в два рази. Дослідження InfoWatch [12] показують, що в 2018 році істотно скоротився обсяг даних, скомпрометованих в результаті витоків 3 організацій сфери високих технологій, фінансовокредитного та страхового сектора, а також підприємств промисловості. При цьому найбільш привабливими для зловмисників продовжують залишатися дані з організацій фінансово-кредитної та страхової сфери, де близько 65\% витоків були вчинені навмисно. Зафіксовано високий інтерес порушників до інформації 3 промислових і транспортних систем, компаній сфер торгівлі і HoReCa, а також високотехнологічного бізнесу більше половини витоків в цих галузях носили умисний характер.

За даними [13], найбільша частка витоків інформації в країнах ЄС та інших розвинутих країнах світу за останні роки здійснюється через мережі загального користування (рис. 3). При цьому, якщо найбільша шкода від крадіжок і шахрайських дій припадає саме на цей сегмент інформаційних інцидентів, то в Україні і в країнах колишнього СРСР найбільшу шкоду завдає саме компроментація паперових носіїв інформації (рейдерські захвати, підміна прав інтелектуальної власності, заміна архівів, тощо). Останнім часом широко використовуються технології викрадення медіафайлів і файлів електронної пошти 3 метою компроментації керівників і власників конкуруючих підприємств, завдання свідомої шкоди їх позитивному іміджу і ослаблення їх позицій на конкурентному ринку.

За даними компанії SecurityLab [14] недобросовісні інсайдери намагаються викрасти або скомпроментувати:

- інформацію про клієнтів і бізнесові оборудки 23\%;

- технічну інформацію -23\%;

- бухгалтерські документи - 14\%;

- фінансові документи (фінансово-економічний аналіз, фінансові моделі, тощо) - 9\%;

- інформацію про закупівлі - 9\%;

- договори - 9\%;

- персональні дані - 1\%;

- іншу інформацію - 14\%.

Слід зазначити, що підприємства несуть не тільки фінансові втрати від діяльності несумлінних інсайдерів. Втрата інформації 3 обмеженим доступом може привести до втрати довіри клієнтів і партнерів, дискредитацією іміджу фірми перед контролюючими органами і владними структурами, небажаних настроїв серед персоналу. 


\section{Висновки та перспективи подальших досліджень}

Підсумовуючи вищенаведене, можна відзначити посилення ролі інформаційної складової у забезпеченні економічної безпеки, зумовлене цифровізацією, інформатизацією і глобалізацією бізнес-процесів. Використання результатів науковотехнічного прогресу викликає появу нових видів, інструментів і продуктів бізнесу, прискорює виробничі процеси, активізує торгівлю і обмін. Разом 3 великою кількістю позитивних ефектів впровадження нових технологій відкриває безліч можливостей нашкодити підприємництву. Суб'єктивний фактор в інформаційній безпеці відіграє вирішальну роль, і можить як нашкодити бізнесу, так і привести до його процвітання. Питання забезпечення інформаційної безпеки суб'єктів господарювання як складової їх економічної безпеки вже давно вийшли за межі галузевих проблем і потребують подальшого ретельного дослідження на рівні держави і суспільства в цілому

\section{СПИСОК ВИКОРИСТАНИХ ДЖЕРЕЛ}

1. Сороківська О. А. Інформаційна безпека підприємства: нові загрози та перспективи. Вісник Хмельницького національного університету. 2010. № 2, т. 2. C. 32-35.

2. Марунич А. В. Захист інформації як основна складова економічної безпеки підприємства. Управління розвитком. 2014. № 14. С. 130132

3. Гордієнко С. Б. Методи та рекомендації забезпечення інформаційної безпеки консалтингової компанії. Вісник ДУІКТ. 2013. № 1. С. 104-107.

4. Державна служба статистики. URL: http://www.ukrstat.gov.ua (дата звернення 15.07.2019).
5. Обсяг піратського програмного забезпечення в Україні становить понад 80\% - дослідження. Інститут масової інформації URL: https://imi.org.ua/news/obsyagpiratskogo-programnogozabezpechennya-v-ukrajini-stanovitponad-80-doslidjennya-i14894 (дата звернення 20.02.2019).

6. Threat Intelligence Index 2019. A Ponemon Institute IBM X-Force Network Report. URL: https://www.ibm.com/account/reg/ us-en/signup?formid=urx-42703. (дата звернення 5.10.2019).

7. Siemens - Industry Automation and Drive Technologies - Service\& Support - SIMATIC WinCC / SIMATIC PCS 7: Information concerning Malware / Virus / Trojan. URL: https://support.industry.siemens.co m/cs/document/43876783 (дата звернення 5.10.2019).

8. Satter, Raphael Ukraine says it foiled 2nd cyberattack after police raid. Associated Press. 5 July 2017.

4. Derzhavna sluzhba statystyky [State Statistics Service]. Retrieved from: http://www.ukrstat.gov.ua. [in Ukrainian].

5. Obsyah pirats'koho prohramnoho zabezpechennya v Ukrayini stanovyt' ponad $80 \%$ - doslidjennya [The volume of pirated software in Ukraine is over $80 \%$ - research]. Instytut masovoyi informatsiyi [Institute of Mass Media]. Retrieved from:

https://imi.org.ua/news/obsyagpiratskogo-programnogozabezpechennya-v-ukrajini-stanovitponad-80-doslidjennya-i14894. [in Ukrainian].
9. Nicolas Falliere, Liam O Murchu, and Eric Chien (Symantec), W32.Stuxnet Dossier, Ver 1.4. February 2011.

10. Frenkel, Sheera Global Ransomware Attack: What We Know and Don't Know. The New York Times. 2017 27 June.

11. Приоритетная угроза - инсайдер Система контроля сотрудников. Стахановец. URL: https://stakhanovets.ru/blog/priorit etnaya-ugroza-insajder.

12. InfoWatch: 23,7\% инцидентов в России - фрод персональных данных. Журнал ПЛАС. URL: https://www.plusworld.ru/daily/cat -security-and-id/infowatch-237incidentov-v-rossii-frod-personal.

13. Allianz Risk Barometer 2015. URL: http://www.agcs.allianz.com/insight s/white-papers-and-casestudies/risk-barometer-2015.

14. SecurityLab 2018 URL http://www.securityLab.com/insigh ts/white-papers-and-casestudies/risk-barometer-2015.

6. Threat Intelligence Index 2019. A Ponemon Institute IBM X-Force Network Report. Retrieved from: https://www.ibm.com/account/reg/ us-en/signup?formid=urx-42703.

7. Siemens - Industry Automation and Drive Technologies - Service\& Support - SIMATIC WinCC / SIMATIC PCS 7: Information concerning Malware / Virus / Trojan. Retrieved from:

https://support.industry.siemens.co $\mathrm{m} / \mathrm{cs} /$ document/43876783.

8. Satter, R. (2017). Ukraine says it foiled 2nd cyberattack after police raid. Associated Press.

9. Falliere, N, Murchu, L. O., and Chien, E. (2011). W32. Stuxnet Dossier, Ver 1.4 . 
10. Frenkel, Sheera. (2017). Global Ransomware Attack: What We Know and Don't Know. The New York Times.

11. Prioritetnaya ugroza - insayder. Sistema kontrolya sotrudnikov [The priority threat is the insider. Employee control system]. (n.d.). Stakhanovets. Retrieved from: https://stakhanovets.ru/blog/priorit etnaya-ugroza-insajder. [in Russian].
12. InfoWatch: $23,7 \%$ intsidentov $v$ Rossii - frod personal'nykh dannykh [InfoWatch: 23,7\% incidents in Russia - personal data fraud]. (2019). PLAS [PLUS]. Retrieved from: https://www.plusworld.ru/daily/cat -security-and-id/infowatch-237incidentov-v-rossii-frod-personal/.
13. Allianz Risk Barometer. (2015). Retrieved from: http://www.agcs.allianz.com/insight s/white-papers-and-casestudies/risk-barometer-2015.

14. SecurityLab. (2018). Retrieved from: http://www.securityLab.com/insigh ts/white-papers-and-casestudies/risk-barometer-2015. 